\title{
MASUUNIKUONAN JA HIENAFOSFAATIN MAATA KALKITSEVA VAIKUTUS PITKÄAIKAISEN LABORATORIOKOKEEN PERUSTEELLA
}

\author{
EUGEN BARKOFF \\ Maatalouden tutkimuskeskus \\ Maanviljelyskemian ja -fysiikan laitos, \\ Tikkurita
}

$\mathrm{M}$ a s u u n i $\mathrm{k}$ o n a n laadussa voi olla hyvin paljon vaihtelua riippuen sekä rautamalmin että teollisuusprosessin laaadusta $(4,8)$. Monissa tapauksissa masuunikuona voi olla hyvää kalkitusainetta, kuten esim. KAPPENin (1) tutkimuksesta ilmenee. Eräät tutkijat (2) ovat esittäneet, että masuunikuonalla ei olisi humusta kuluttavaa vaikutusta sillä tavoin kuin tavallisilla kalkitusaineilla. Tämä johtuisi todennäköisesti siitä, että masuunikuonassa on neutraloivana aineena kalsiumsilikaatti. Schachtschabel (5) ei kuitenkaan voinut todeta, että masuunikuona kuluttaisi vähemmän humusta kuin muut kalkitusaineet.

Ainakin eräissä tapauksissa masuunikuona voi sisältää viljan korren lujuutta lisäävää liukenevaa piihappoa ja hyödyllisiä hivenaineita.

Mainittakoon, että Tomula ja Purokoski (7) ovat tehneet tutkimuksen muunlaisen kalsiumsilikaatin maata kalkitsevasta vaikutuksesta päätyen positiiviseen tulokseen.

Kun on todennäköistä, että rautateollisuus Suomessa tulee laajenemaan ja siten saadaan ehkä paljonkin masuunikuonaa, pantiin Maatalouden tutkimuskeskuksen maanviljelyskemian ja -fysiikan laitoksessa syksyllä 1951 alkuun pieni koe laboratoriomittakaavassa masuunikuonan vaikutuksien selvittämiseksi. Erityisesti oli tarkoitus saada tietoja masuunikuonan vaikutuksesta maan humuspitoisuuteen.

Masuunikuona saatiin Outokumpu Oy:ltä, joka oli tuottanut pienen erän Outokummun rautamalmin käsittelyssä ulkomailla saatua masuunikuonaa takaisin Suomeen, jotta voitaisiin tutkia sen käyttökelpoisuutta maanparannusaineeksi. Samaa masuunikuonaerää on käytetty myös muutamissa kenttäkokeissa, joiden tulokset ovat vielä julkaisematta, mutta voidaan mainita, että niissä on masuuni- 
kuonan vaikutus satoihin ollut suunnilleen sama tai jopa parempi kuin vastaavan määrän kalkkikivijauhetta. Tämä näyte-erä sisälsi tavanomaisella määritysmenetelmällä saatavaa neutraloivaa kalkkia $\mathrm{CaO}$ :ksi laskettuna $48 \%$, ja oli siinä suhteessa lähellä tavallista kalkkikivijauhetta.

Varsinkin viljelijöiden taholta on esitetty ajatusta, että ns. hi e n o f o sf a a t $\mathrm{i}$ voisi olla edullinen maan kalkkitilan parantaja, koska siinä joudutaan maksamaan hinta vain fosforista (sekin vielä halpa), joten sen sisältämä kalsium saadaan ilmaiseksi. Varsinaista neutraloivaa kalkitusvaikutusta voi tietenkin olla vain hienofosfaatissa vähässä määrässä (n. 14-15\%) esiintyvällä kalsiumkarbonaatilla, joka vastaa n. $7-7.5 \%$ neutraloivaa kalkkia. Kokeessa käytetty hienofosfaatti oli tavallista kauppatavaraa, jonka fosforipitoisuus oli $28.5 \% \mathrm{P}_{2} \mathrm{O}_{5}$. Ns. neutraloivan kalkin määritystä tavanomaisella menetelmällä ei siitä tehty, sillä se ei kuitenkaan olisi onnistunut fosforihapon vahvan puskuroivan vaikutuksen vuoksi.

Vertailun vuoksi otettiin mukaan myös tavallinen $\mathrm{kalk} \mathrm{kikivijauhe.}$

Koemaina oli 3 Maatalouden tutkimuskeskuksen maatilan pelloilta otettua maanäytettä, joiden ominaisuudet olivat:

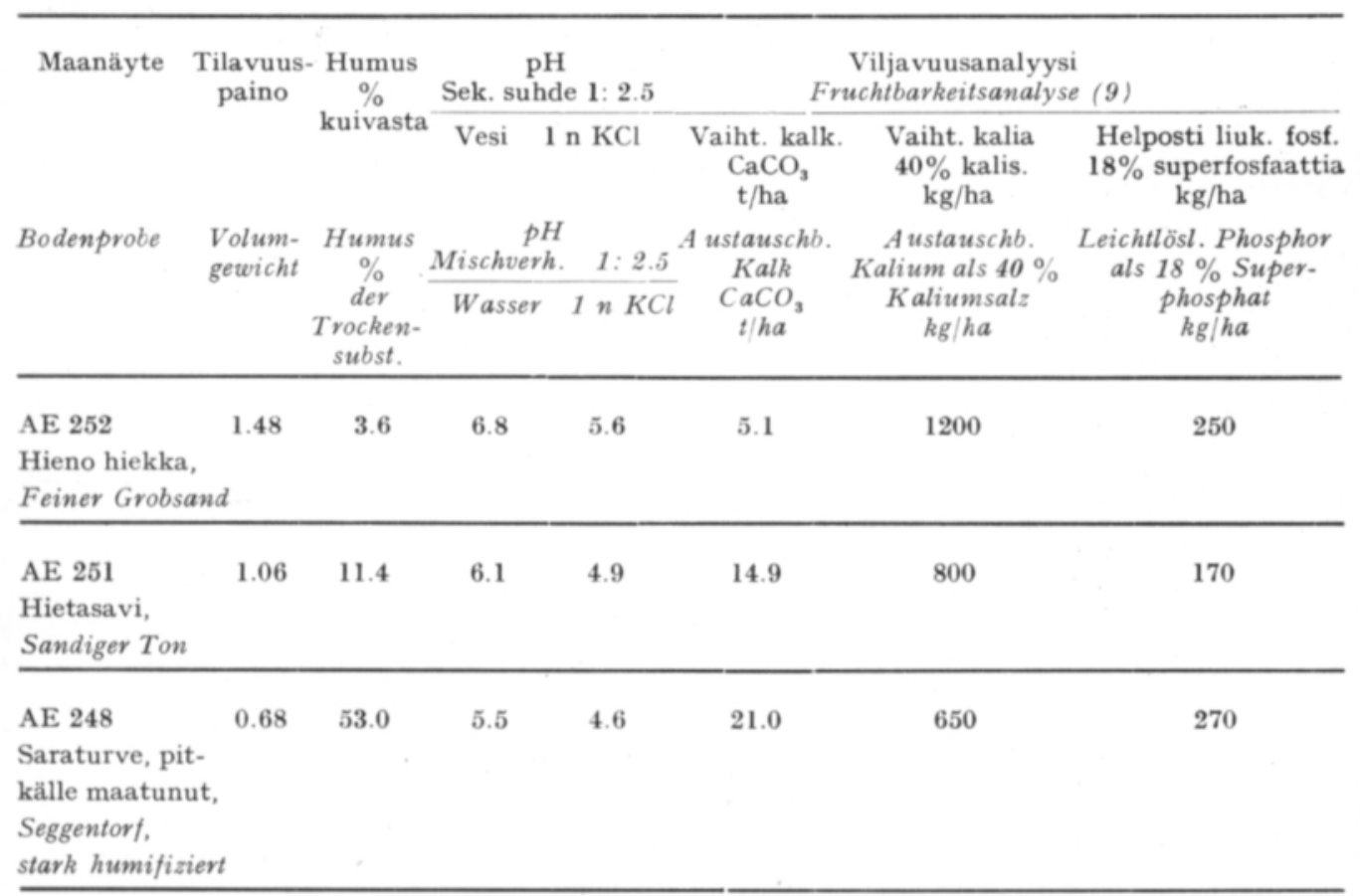




\section{Kokeen järjestely ja suoritus}

Koetta varten punnittiin kutakin koemaata tilavuuspainon mukaan $250 \mathrm{ml}$ vastaavat erät ns. kiteyttämisastioihin ja niihin sekoitettiin kokeiltavia kalkitusaineita seuraavasti:

$\begin{array}{lllcrr}\text { määrä } \mathrm{mg} / 250 \mathrm{ml} & 0 & 313 & 625 & 1250 & 2500 \\ \text { vastaa } \mathrm{tn} / \mathrm{ha} & 0 & 2.5 & 5 & 10 & 20 \\ \text { merkintä } & 0 & 1 & 2 & 4 & 8\end{array}$

Kaikkia tutkittavia aineita käytettiin siten samoja määriä riippumatta eroista niiden vaikuttavien aineiden pitoisuuksissa. Samaten on kaikille maalajeille käytetty samoja määriä huolimatta suurista eroista niiden ominaisuuksissa.

Lopuksi maat kostutettiin lähelle ns. kenttäkapasiteettia. Vesimääriksi tuli eri maalajeissa: hieno hiekka 9, hietasavi 25 ja saraturve 45 paino- $\%$. Astiat peitettiin lasilevyillä ja niitä säilytettiin huonelämmössä $\left(17-21^{\circ} \mathrm{C}\right)$. Noin kuukauden väliajoin astiat punnittiin ja haihtunut vesi korvattiin.

Kokeen alkupuolella tehtiin koeastioista useaan otteeseen $\mathrm{pH}$-määrityksiä ja lopuksi suoritettiin monipuolisempi tutkimus.

\section{Eri kalkitusaineiden vaikutus maan $\mathrm{pH}$-arvoihin}

Kokeessa olleista astioista tehtiin pH-mittauksia 1/2, 1, 4 ja 8 kuukauden kuluttua kokeen alkamisesta sekä lopuksi 9 vuoden koeajan jälkeen. Mittaukset tehtiin tavalliseen tapaan vesilietoksessa maa:vesi 1: 2.5 .

Mittausten tulokset esitetään piirroksissa 1, 2 ja 3 .

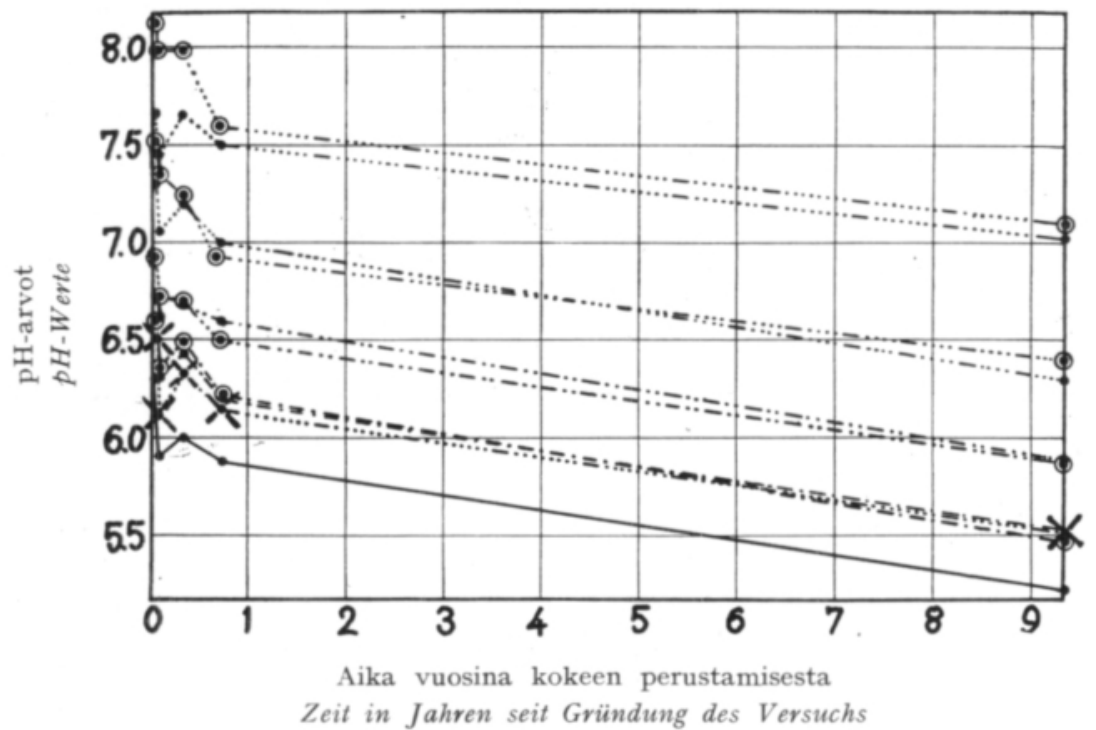

Piirros 1. pH-arvojen muutokset hienossa hiekassa. Kalkitusaineiden merkit: piste = kalkkikivijauhe, piste ja rengas $=$ masuunikuona ja risti $=$ hienofosfaatti. Pisteitten luku viivoissa ilmaisee kalkitusaineen määrää, piste $=$ pienin määrä, 2 pistettä $=$ määrä 2 jne.

$A b b$. 1. Veränderungen der $p H$-Werte bei feinem Grobsand. Bezeichnung der Kalkformen: Punkt $=$ Kalksteinmehl, Punkt und Kreis = Hüttenkalk sowie Kreuz = feingemahlenes Rohphosphat. Die Anzahl der Punkte in den Linien stellt die Menge der Kalkform dar, ein Punkt $=$ kleinste Menge, zwei Punkte $=$ zwei- 


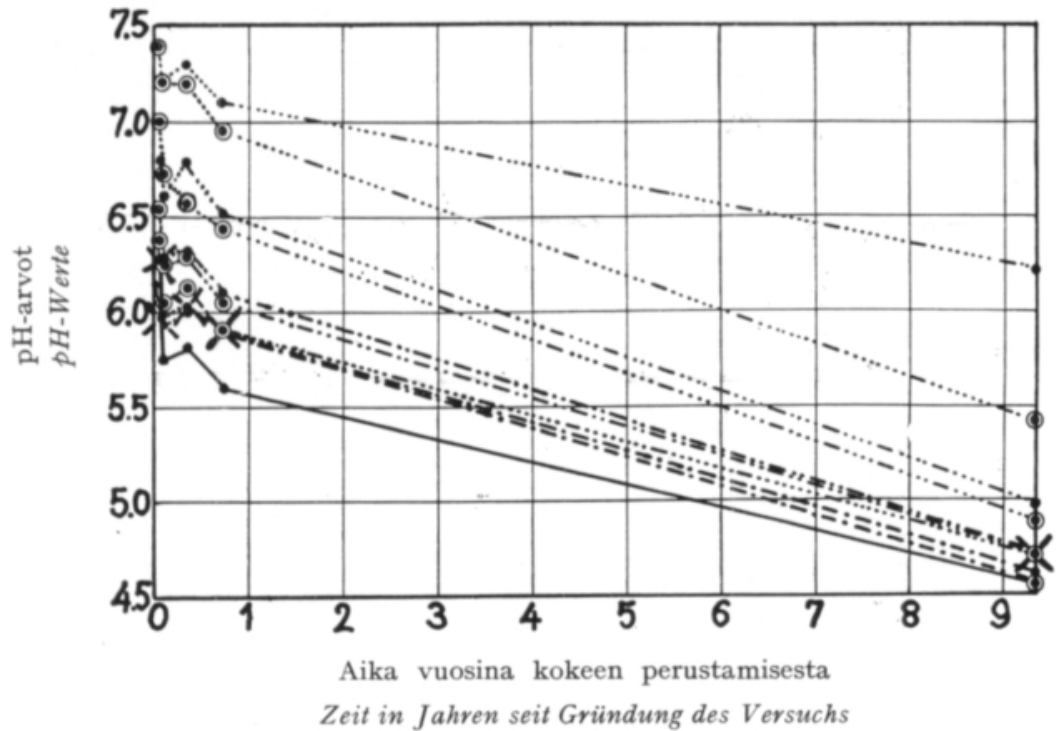

Piirros 2. pH-arvojen muutokset hietasavessa. Merkit kuten piirroksessa 1.

Abb. 2. Veränderungen der $p H$-Werte bei sandigem Ton. Bezeichnungen wie in Abb. 1 .

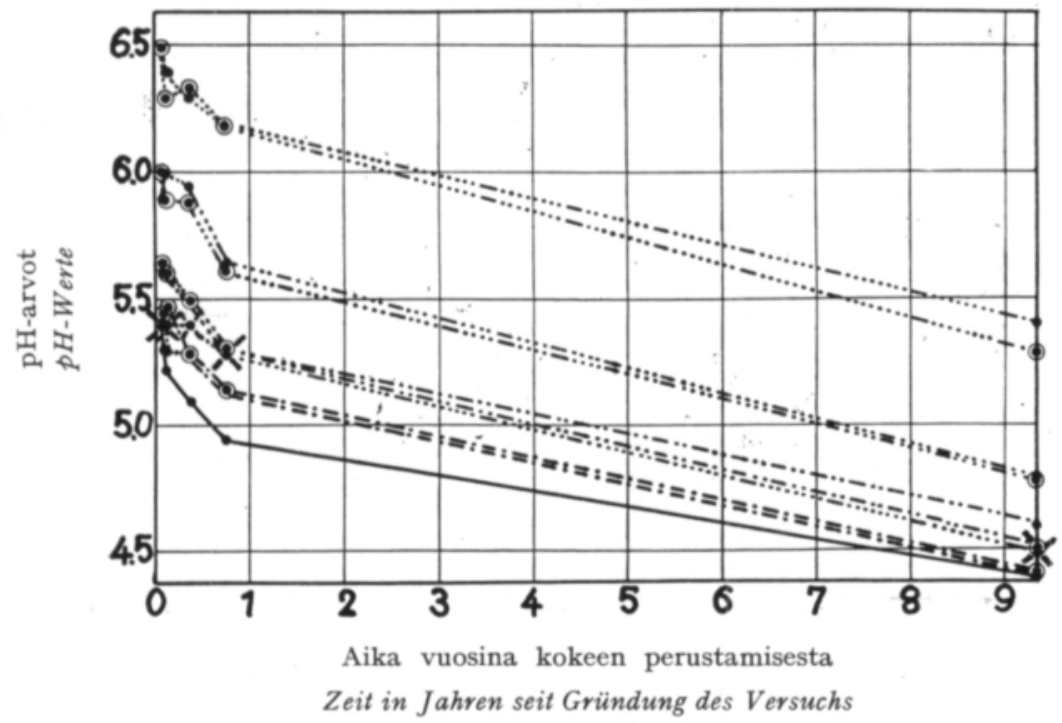

Piirros 3. pH-arvojen muutokset pitkälle maatuneessa turpeessa. Merkit kuten piirroksessa 1.

$A b b$. 3. Veränderungen der $p H$-Werte bei stark humifiziertem Seggentorf. Bezeichnungen wie in Abb. 1 .

Kaikissa pH-arvoja esittävissä käyrissä voidaan todeta selvä lasku koekauden aikana. Se on ilmiö, joka tulee esiin aina, kun maata säilytetään kostutettuna huonelämmössä, ja päätekijänä siinä on nitraatin muodostumisesta johtuva elektrolyyttien lisääntyminen (6).

Vaikka pieniä säännöttömyyksiä esiintyykin, voidaan sanoa, että masuuni- 
kuonan vaikutus maan $\mathrm{pH}$-arvoon on ollut sama kuin kalkkikivijauheen. Näin on kaikissa maalajeissa ja kaikilla kokeessa mukana olleilla määrillä. Hienofosfaatista on piirroksiin otettu vain suurimmalla määrällä $\left(\mathrm{hf}_{8}\right)$ saadut tulokset, sillä muut käyrät olisivat sijoittuneet ahtaalle alueelle sen ja kalkitsemattoman $(\mathrm{O})$ välille. Suurimman hienofosfaattimäärän käyrä on suunnilleen samassa tasossa kuin muiden aineiden pienimmän määrän käyrä. Siten voidaan sanoa, että hienofosfaatin maata neutraloiva vaikutus on suunnilleen 1/8 kalkkikivijauheen tai masuunikuonan vastaavasta. Tämän mukaan hienofosfaatin maata kalkitseva vaikutus riippuu kokonaan sen karbonaatista, kuten oli odotettavissakin.

\section{Kalkitusaineiden vaikutus maan humuspitoisuuteen}

Koemaista tehtiin humuspitoisuusmääritykset 1,5 ja 9 vuoden vaikutusajan jälkeen. Kun lyhyessä vaikutusajassa ei tullut mitään eroja näkyviin, jätetään näiden kahden ensimmäisen määrityksen tulokset esittämättä ja tyydytään vain kokeen lopussa saatujen tulosten graafiseen esittämiseen piirroksessa 4 . Kun varsinkin

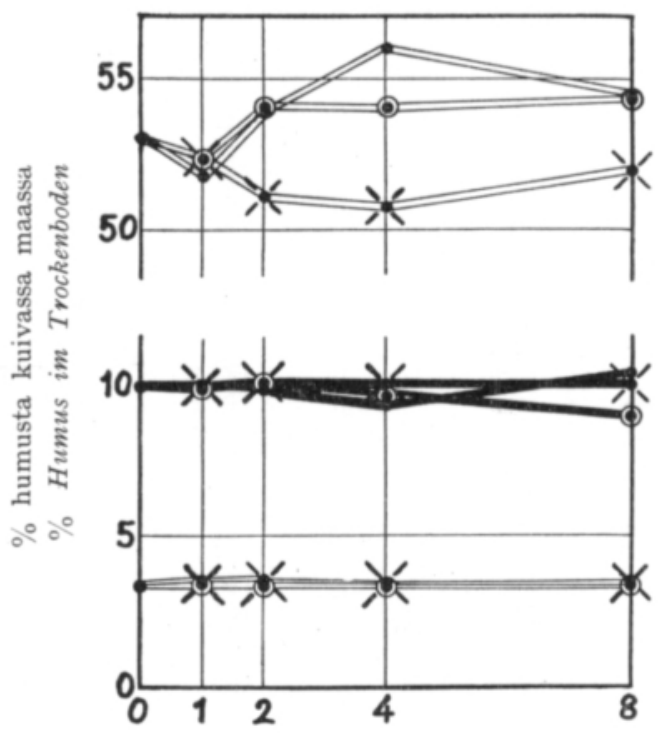

Kalkitusaineiden suhteelliset määrät Relative Mengen der Kalkformen

Piirros 4. Humuspitoisuudet kokeen lopussa. Maalajien merkit: ohut viiva = hieno hiekka, paksu viiva $=$ hietasavi ja kaksoisviiva $=$ pitkälle maatunut saraturve. Kalkitusaineiden merkit kuten piirroksessa 1.

Abb. 4. Humusgehalte am Schluss des Versuchs. Bezeichnung der Bodenarten: dünne Linie = feiner Grobsand, dicke Linie = sandiger Ton und Doppellinie $=$ stark humifizierter Seggentorf. Bezeichnung der Kalkformen wie in Abb. 1.

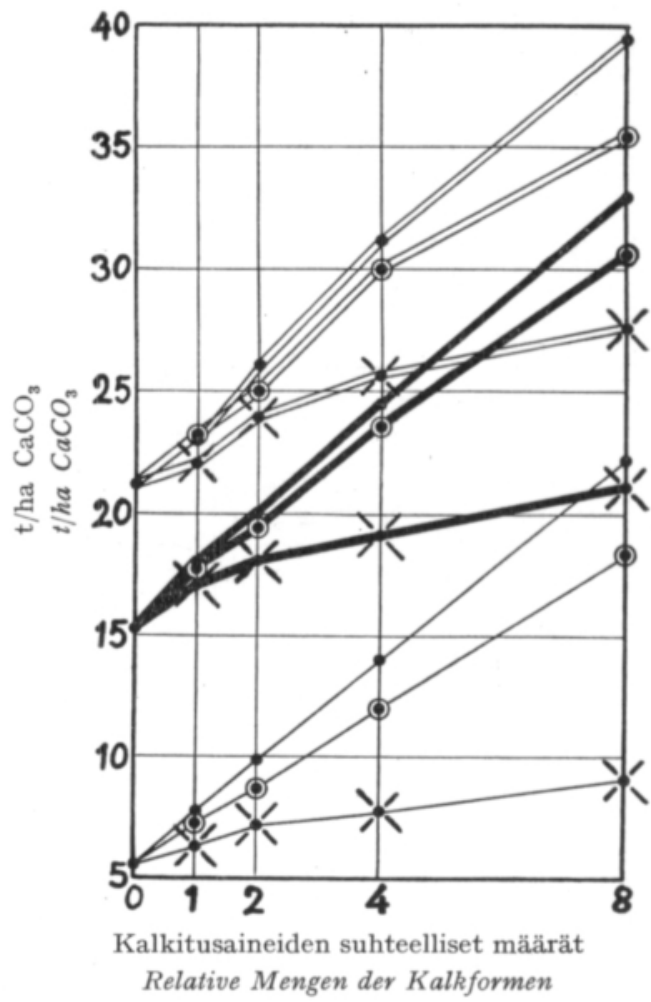

Piirros 5. Viljavuusanalyysissä kokeen lopussa saadut vaihtuvan kalkin määrät. Merkit kuten piirroksessa 4.

Abb. 5. Die durch eine sog. Fruchtbarkeitsanalyse am Schluss des Versuchs erhaltenen Mengen an austauschbarem Kalk. Bezeichnungen wie in Abb. 4. 
korkeimmat kalkitusmäärät (8) ovat melkoisen suuret $(0.7-1.5 \%$ maan painosta), on se otettu huomioon humuspitoisuuksia laskettaessa, jotta eri määrillä $(0-8)$ saadut luvut olisivat toisiinsa verrattavia.

Voidaan todeta, että millään käytetyllä aineella ja millään määrällä ei ole ollut vaikutusta maan humuspitoisuuksiin. Saraturpeen humuspitoisuutta esittävissä käyrissä on kyllä hieman eroja, mutta ne johtuvat todennäköisesti näytteenotto- ja analyysivirheistä, joita juuri turvemaan kohdalla tulee eniten. Ettei voi olla kysymys todellisista muutoksista, voidaan päätellä esim. siitä, että hienofosfaatin käyrä tulee alimmaksi, mutta juuri siltä voi vähiten odottaa humusta kuluttavaa vaikutusta. - Näiden havaintojen mukaan ei millään kalkitusaineella ole kokeessa vallinneissa olosuhteissa ollut vaikutusta maan humusmääriin, vaikka edellytykset vaikutuksen esille tulemiseen ovat olleet melko hyvät, nim. korkea lämpötila (huonelämpö), jokseenkin sopiva kosteus ja pitkä aika (9 vuotta).

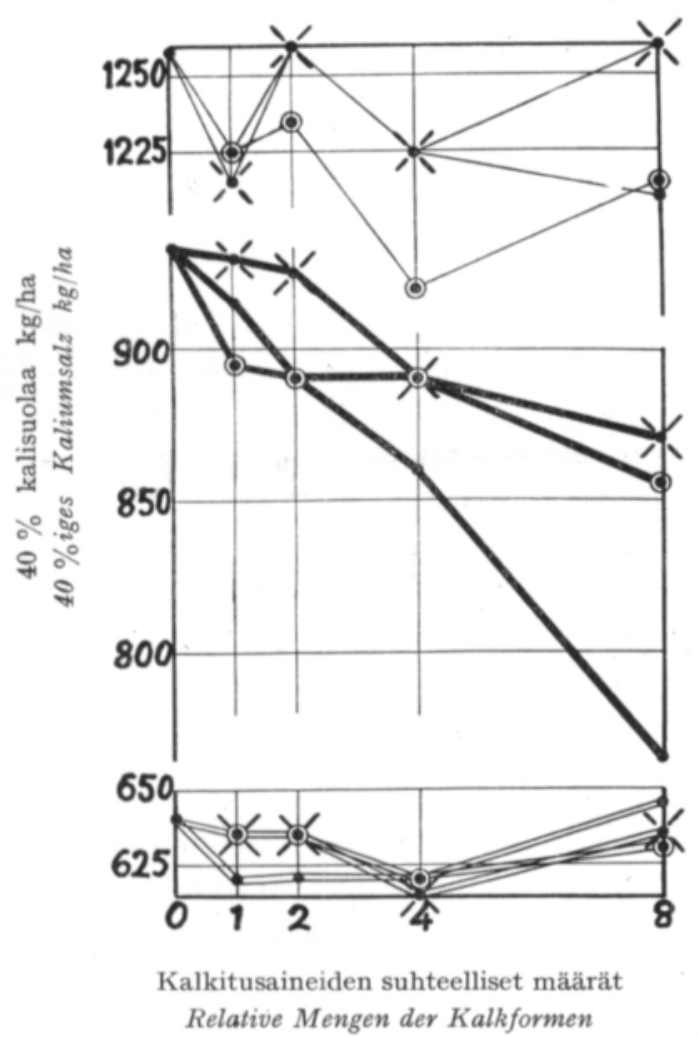

Piirros 6. Viljavuusanalyysissä kokeen lopussa saadut vaihtuvan kalin määrät. Merkit kuten piirroksessa 4.

Abb. 6. Die durch eine sog. Fruchtbarkeitsanalyse am Schluss des Versuchs erhaltenen Mengen an austauschbarem Kalium. Bezeichnungen wie in Abb. 4.

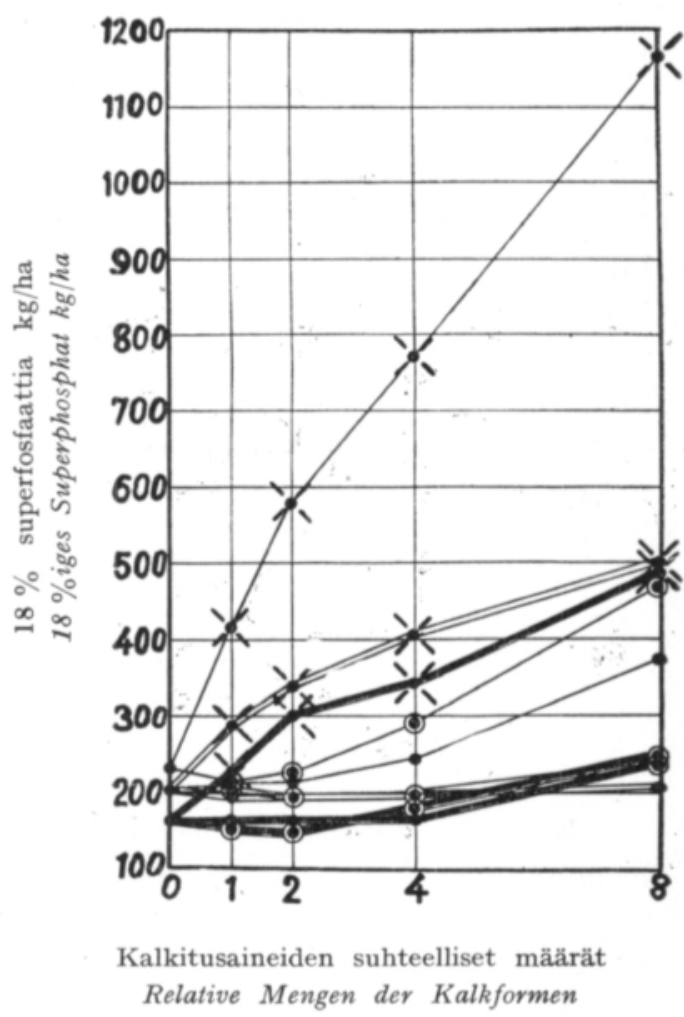

Piirros 7. Viljavuusanalyysissä kokeen lopussa saadut helposti liukenevan fosforin määrät. Merkit kuten piirroksessa 4.

Abb. 7. Die durch eine sog. Fruchtbarkeitsanalyse am Schluss des Versuchs erhaltenen Mengen an leichtlöslichem Phosphor. Bezeichnungen wie in Abb. 4. 
Koekauden jälkeen tehtiin maanäytteistä eräiden aineiden määritykset viljavuustutkimuksessa käytetyllä ammoniumasetaattimenetelmällä (9). Määritysten tulokset esitetään graafisesti piirroksissa 5, 6 ja 7 .

$\mathrm{K}$ a ls i u m luvu is t a täytyy sanoa, että niiden merkitys maan kalkkitilan kuvastajana on tällaisessa tapauksessa hyvin kyseenalainen, sillä uuttonesteeseen voi tulla paitsi vaihtuvaa kalsiumia myös kalkitusaineen vielä muuttumattomana olevaa kalsiumia. Kuten piirroksen 5 käyristä näkyy, vain osa lisätystä kalkista on tullut analyysissä näkyviin. Suurimpiin arvoihin on päästy kalkkikivijauheella, masuunikuonalla saadut arvot jäävät selvästi alemmiksi ja hienofosfaatin kalsiumarvoja lisäävä vaikutus on jäänyt vähäiseksi.

K a liumarvoissa, piirros 6, ei voi odottaa olevan paljoakaan eroja, koska koekäsittelyissä ei ole tullut lainkaan kalia. Hienon hiekan ja saraturpeen kaliarvot ovat hyvin samat kaikilla eri käsittelyillä, mutta hietasaven kaliluvut laskevat sitä enemmän, mitä enemmän kalkitusainetta on annettu. Tehokkain tässä suhteessa näyttää olevan kalkkikivijauhe. Tässä on nähtävästi kysymys kalin muuttumisesta vaihtumattomaksi (3).

Saadut fosforiarvot esitetään piirroksessa 7. On selvää, että fosforilannoitteen, vaikka se olisikin vaikeasti liukenevaa, lisääminen vaikuttaa fosforilukuihin. Eniten tuntuu lisäys hienossa hiekassa, vähemmän ja keskenään suunnilleen yhtä paljon hietasavessa ja saraturpeessa. Niissä on molemmissa ilmeisesti paljon fosforia pidättäviä aineita. Varsinaiset kalkitusaineetkin ovat varsinkin runsain määrin käytettynä nostaneet fosforilukuja, minkä täytyy johtua kalkituksen maan fosforia mobilisoivasta vaikutuksesta, sillä kalkkikivijauheessa enempää kuin masuunikuonassa ei ole ollut lainkaan fosforia. Näyttäisi vielä siltä, että masuunikuona olisi lisännyt liukoista fosforia hieman tehokkaammin kuin kalkkikivijauhe.

\section{Ti ivistelmä}

Noin 9 vuotta kestäneessä, laboratoriossa suoritetussa masuunikuonan ja hienofosfaatin kalkitusvaikutusta koskevassa kokeessa tuli seuraavat tulokset:

Masuunikuonan maata neutraloiva vaikutus oli sama kuin kalkkikivijauheen, mutta hienofosfaatin mitättömän vähäinen.

Millään kalkitusaineella ei ollut vaikutusta maan humuksen määriin, vaikka käytetyt määrät olivat suuria, olosuhteet pieneliötoiminnalle edulliset ja vaikutusaika pitkä.

Kalkitusaineet lisäsivät tavanmukaisessa maa-analyysissä saatavan kalsiumin määrää. Vaikutus kalin määriin oli pieni, mutta savimaassa esiintyi kalilukujen alenemista. Fosforiarvoihin oli hienofosfaatilla tietenkin suuri vaikutus, mutta myös muut kalkitusaineet lisäsivät helposti liukenevan fosforin määriä. 


\section{KIRJALLISUUTTA}

(1) KAppen, H. W. 1947. Neuere Erfahrungen bei der Düngung mit Hüttenkalk. Stahl u. Eisen 66/67: $307-312$.

(2) - - \& Scharpenseel, H. W. 1951. Weitere Untersuchungen über die humusschonende Wirkung des Hüttenkalkes. Z. Pfl. Düng., Bodenkunde 53 (98): 36-47.

(3) KeRĀNEn, T. 1946. Kaliumista Suomen maalajeissa. Summary: On potassium in Finnish soils. Acta agr. fenn. 63: 1-114.

(4) Naumann, G. 1939. Uber die Zersetzung von Eisenhochofenschlacken. Z. Pfl. Düng., Bodenkunde $15(60): 74-126$.

(5) SснаснтsснавеL, P. 1953. Die Umsetzung der organischen Substanz des Bodens in Abhängigkeit von der Bodenreaktion und der Kalkform. Ibid 61 (106): 146-163.

(6) Teräsvuori, A. 1930. Uber die Bodenazidität mit besonderer Berücksichtigung des Elektrolytgehaltes der Bodenaufschlämmungen. Valt. maatal. koet. julk. 29: 1-215.

(7) Tомula, E. S. \& Purokosкi, P. 1948. Uber die Anwendung des künstlichen Calciummetasilicats zur Verbesserung saurer Böden. Suomen Kemistilehti 21 B: $35-42$.

(8) Torstensson, G. \& Alvelid, S. 1952. Om användning av masugnsslagg som kalkningsmedel i jordbruket. Lantbr. Akad. tidskrift 91: $57-76$.

(9) Vuorinen, J. \& Mäkitie, O. 1955. The method of soil testing in use in Finland. Agro-geol. julk. 63: $1-44$.

R E F E R A T:

UBER DIE KALKUNGSWIRKUNG VON HUUTTENKALK UND FEINGEMAHLENEN ROHPHOSPHAT AUF GRUND EINES LANGWÄHRENDEN LABORATORIUMSVERSUCHS

EUGEN BARKoFF

Zentrale für landwirtschaftliche Forschung

Abteilung für Agrikulturchemie und -physik

Tikkurila, Finland

In dem vorliegenden Artikel wird ein etwa 9 Jahre dauernder Laboratoriumsversuch beschrieben. Bei Gründung des Versuchs wurden drei verschiedenartige Böden, nämlich feiner Grobsand, sandiger Ton und stark humifizierter Seggentorf, ausgewählt (Tabelle S.195). Nach diesem wurde die Kalkungswirkung von gewöhnlichem Kalksteinmehl, einem durch Bearbeitung von Eisenerz aus Outokumpu hergestellten Hüttenkalk $(\mathbf{4 8} \%$ neutralisierendes $\mathrm{CaO})$, und von tunisischem feingemahlenem Rohphosphat $\left(28.5 \% \mathrm{P}_{2} \mathrm{O}_{5}\right)$ auf die genannten Böden untersucht.

$\mathrm{Zu}$ diesem Zweck mass man die erforderliche Anzahl von $250 \mathrm{ml}$ grossen Proben der Versuchsböden in sog. Kristallisationsschalen, wobei folgende Mengen der untersuchten Kalkformen in diese homogen eingemischt wurden:

Menge $\mathrm{mg} / 250 \mathrm{ml}$
entspricht $\mathrm{tn} / \mathrm{ha}$
Bezeichnung in $\mathrm{Abb}$.

Die Böden wurden beinahe bis zur Feldkapazität mit Wasser angefeuchtet, die Schalen mit Glassscheiben bedeckt und bei Zimmertemperatur $\left(17-21^{\circ}\right)$ aufbewahrt. Die Schalen wurden etwa einmal monatlich gewogen und das verdunstete Wasser durch neues ersetzt. 
Während des ersten Jahres wurden die pH-Werte der Versuchsböden bei einem Volumenverhältnis von Boden: Wasser =1: 2,5 mehrmals bestimmt und am Schluss des Versuchs eine vielseitigere Untersuchung der Böden ausgeführt.

Mit der Zeit sind alle pH-Werte aller Versuchsböden und bei allen Kalkformen gesunken, was hauptsächlich auf einer Nitratbildung beruht (Abb. 1, 2 und 3).

Die neutralisierende Wirkung von Hüttenkalk war beinahe gleich gross wie die von Kalksteinmehl, aber die von feingemahlenem Rohphosphat war ganz minimal.

Die Ergebnisse der kolorimetrischen Humusbestimmung am Schluss des Versuchs durch Oxydation in Chromschwefelsäure sind in Abb. 4 graphisch dargestellt. Keine der gebrauchten Kalkformen wirkte auf die Humusmenge der Böden ein, obgleich die Mengen der Kalkformen gross, die Verhältnisse für die Tätigkeit von Mikroorganismen günstig und die Einwirkungszeit lang war.

Die gewöhnliche, sog. Fruchtbarkeitsanalyse (9) durch Extraktion der Versuchsböden mit einer Pufferlösung (pH-Wert 4.65), die sowohl für $\mathrm{CH}_{3} \mathrm{COONH}_{4}$ als für $\mathrm{CH}_{3} \mathrm{COOH} 0.5 \mathrm{n}$ war, ergab folgendes:

1. Alle Kalkformen haben die dabei erhaltenen Kalziummengen vergrössert (Abb. 5).

2. Ihre Einwirkung auf Kaliummengen war sonst gering. Nur bei sandigem Ton kam eine Verminderung der Kaliumwerte durch Kalkung vor (Abb. 6).

Die Einwirkung auf die Phosphorwerte durch Rohphosphat war selbstverständlich gross, aber auch die anderen Kalkformen haben die Mengen des leichtlöslichen Phosphors vergrössert (Abb. 7). 